\title{
Yttria-stabilized zirconia-alumina composite sintering temperature effect on thermal diffusivity
}

\author{
Kamil Dychtoń $^{1} \cdot$ Marcin Drajewicz $^{1} \cdot$ Maciej Pytel $^{1} \cdot$ Paweł Rokicki $^{1} \cdot$ \\ Andrzej Nowotnik ${ }^{1}$
}

Received: 15 November 2015/ Accepted: 18 August 2016/Published online: 31 August 2016

(C) The Author(s) 2016. This article is published with open access at Springerlink.com

\begin{abstract}
Yttria-stabilized zirconia (YSZ) is one of the most common materials used for a ceramic top coat in the thermal barrier coating (TBC). The high operating temperature used in the gas turbine engines causes the stress between the top coat and the bond coat. The stress relaxation can be assured by modifications of YSZ. Hence, studies on how to modify the chemical and phase composition of these coatings are still conducted. The laser flash analysis was used to determine the thermal diffusivity of composite mixture of $8 \mathrm{~mol} \%$ yttria-stabilized zirconia with $\alpha-\mathrm{Al}_{2} \mathrm{O}_{3}$ in the range of temperatures between 20 and $1100{ }^{\circ} \mathrm{C}$. The powders were prepared with 5 and 25 mass $\%$ $\mathrm{Al}_{2} \mathrm{O}_{3}$ addition to $8 \mathrm{YSZ}$. The particle size distribution was done for each powder to analyse the grain size after milling of the $\alpha-\mathrm{Al}_{2} \mathrm{O}_{3}$ with $8 \mathrm{YSZ}$ in the ball mill. The density of each powder was measured in the helium pycnometer. The disc-shaped samples were produced by pressing using an isostatic press and then sintered at various temperatures: $1000,1200,1400$ and $1600{ }^{\circ} \mathrm{C}$.
\end{abstract}

Keywords Laser flash analysis $\cdot \mathrm{Al}_{2} \mathrm{O}_{3}-\mathrm{YSZ}$ composite . Thermal diffusivity

\section{Introduction}

Yttria-stabilized zirconia (YSZ) is the current state-of-theart material widely used to protect heavily loaded parts of the stationary gas turbines and the parts in hot section of

Kamil Dychtoń

kdychton@prz.edu.pl

1 Rzeszow University of Technology, Al. Powstancow Warszawy 12, 35-959 Rzeszow, Poland aircraft engines. The most advanced protective coatings are thermal barrier coatings (TBCs) which usually are consisted of two coatings: the first one is a diffusion aluminide coating (bond coat), and the second one is an outer ceramic coating (top coat). The main role of the TBC is to provide thermal insulation of the turbine blade (made from nickelbase superalloy). Such a coating may have a lamellar or columnar structure and can be prepared by various methods, such as air plasma spraying (APS), electron beamphysical vapour deposition (EB-PVD) or plasma sprayphysical vapour deposition (PS-PVD). Depending on its structure and thickness can reduce the substrate temperature by up to $200{ }^{\circ} \mathrm{C}$ [1-5]. Development of the gas turbine is aimed to produce engines that will be able to withstand increased turbine entry temperature (TET), well beyond $1600{ }^{\circ} \mathrm{C}[6-9]$. The higher operating temperature in the gas turbine engines the more improvements in the TBCs development for turbine blades based on nickel superalloys [10]. Traditionally, $\mathrm{ZrO}_{2}$ that has been partially stabilized with $8 \mathrm{~mol} \% \mathrm{Y}_{2} \mathrm{O}_{3}$ is used for TBCs. Unfortunately, YSZ coatings show insufficient phase stability and accelerated sintering at temperatures higher than $1200{ }^{\circ} \mathrm{C}$ [9]. Therefore, it is crucial to search for alternative stabilizers or alternative materials for TBCs, with improved phase stability.

At the room temperature, the structure of pure zirconia $\mathrm{ZrO}_{2}$ is monoclinic, but in higher temperatures it undergoes monoclinic-tetragonal and tetragonal-cubic structural phase transitions (at 1167 and $2397{ }^{\circ} \mathrm{C}$ ) [11]. However, the fluorite-type cubic structure of the high-temperature phase can exist at room temperature by doping lower-valent metal oxides like $\mathrm{Y}_{2} \mathrm{O}_{3}$, which is so-called yttria-stabilized zirconia (YSZ) [11]. Yttria is the most popular stabilizer used for zirconia ceramics for its excellent mechanical and wear properties and a good effect on tetragonal phase 
transformability [12]. Unfortunately, YSZ coatings show phase instability and accelerated sintering at temperatures higher than $1200{ }^{\circ} \mathrm{C}$ for TBCs systems. Thermal shock and failure occur during rapid cooling. The monoclinic to tetragonal phase transformation results in a volume change and from that causes high stresses [13]. Therefore, the monoclinic phase formed by phase transformation during temperature variation causes rapid spallation of the TBC. Not even a strain-tolerant, columnar microstructure can accommodate these stresses. Thermal shock resistance of cubic $8 \mathrm{~mol} \%$ YSZ can be increased by the addition of dilute second phase [14]. That second phase can be $\alpha$ $\mathrm{Al}_{2} \mathrm{O}_{3}$. Many studies have reported that $\mathrm{Al}_{2} \mathrm{O}_{3}$ addition to YSZ not only assisted sintering but also lowered the overall and grain-boundary resistivity of YSZ [15]. This mixture of YSZ and $\mathrm{Al}_{2} \mathrm{O}_{3}$ can be prepared as powder for the lowpressure plasma spraying (LPPS) or as ceramic bars for electron beam-physical vapour deposition (EB-PVD) and used for creation of top coat in TBCs system [16-18]. It is crucial to measure the thermal diffusivity of the ceramic powders to compare it with the thermal diffusivity of ceramic topcoat deposited on the surface of the turbine blades.

This study addresses how dilute second phase affects the thermal diffusivity for two-phase ceramic composites of $8 \mathrm{~mol} \% \mathrm{YSZ}$ with alumina oxide $\left(\alpha-\mathrm{Al}_{2} \mathrm{O}_{3}\right)$ after sintering in the range of temperature $1000-1600{ }^{\circ} \mathrm{C}$. Experimental characterization of the thermal diffusivity for ceramics composite was performed using the laser flash method (LFA) in the range of temperatures between 20 and $1100{ }^{\circ} \mathrm{C}$.

\section{Experimental}

In this paper, the thermal diffusivity of yttria-stabilized zirconia (YSZ) with $\alpha-\mathrm{Al}_{2} \mathrm{O}_{3}$ composite was measured by laser flash analysis [19, 21-23]. This method is based on monitoring the temperature excursion generated on the sample back face resulting from deposition of a very short but intense laser energy pulse on rear face surface of a sample. Due to the heat loss effects-especially for high temperature - the data reduction need to be accounted [20]. This is done by the formula available in the software of LFA 447 Netzsch Instruments. The analysis of the data was done in connection with the radiation model design for the measurement of ceramic. The voltage of the laser used in the laser flash analysis was $600 \mathrm{~V}$, and the pulse width was equal to $0.5 \mathrm{~ms}$ for all measurements. Samples which can be measured in laser flash technique need to have a disc shape. Yttria-stabilized zirconia-alumina $\left(\mathrm{YSZ}_{-}-\mathrm{Al}_{2} \mathrm{O}_{3}\right)$ composites containing 5 and 25 mass $\%$ of $\alpha-\mathrm{Al}_{2} \mathrm{O}_{3}$ were mixed in a ball mill to ensure homogeneity. Density of ceramic composites was measured in the helium pycnometer. In this measurement, the inert gas is used as the displacement medium. The sample solid-phase volume is measured by comparison with pressure of gas in the sample chamber with the same volume of gas after discharging into a second empty chamber. Dividing the sample weight by measured volume gives the bulk density. The density was measured ten times, and average value is presented in Table 1. The flat samples were formed in the shape of cylinder with diameter equal $12.5 \mathrm{~mm}$. To appropriate quantification of powder, three drops of glycerine were added before pressing. The forming of powder to the stiff and flat samples was realized in a one direction manually operated hydraulic press with a pressure force $200 \mathrm{kN}$ at room temperature. Samples were sintered in, respectively, temperature $1000,1200,1400$ and $1600{ }^{\circ} \mathrm{C}$ for $4 \mathrm{~h}$ with slow cooling to room temperature. Before analyses, both surfaces of samples were covered with graphite. The black coating to absorb the laser beam energy is required for the specimen which is transparent, translucent or low emissivity. The SEM microscopic investigation of pressed and sintered $\mathrm{Al}_{2} \mathrm{O}_{3}-\mathrm{YSZ}$ composites were carried out using Hitachi S3400 N scanning electron microscope equipped with X-ray energy dispersive spectrometer (EDS). The results of SEM research are presented in Figs. 7 and 8. The particle size distribution was done for powder of 5 and 25 mass $\% \mathrm{Al}_{2} \mathrm{O}_{3}-\mathrm{YSZ}$ composites in the DigiSizer II and is presented in Fig. 10.

\section{Results}

The density of the 5 and 25 mass $\% \mathrm{Al}_{2} \mathrm{O}_{3}-\mathrm{YSZ}$ composites is presented in Table 1 . The value of the density for the 25 mass $\% \mathrm{Al}_{2} \mathrm{O}_{3}-\mathrm{YSZ}$ composite is smaller than the density for the 5 mass $\% \mathrm{Al}_{2} \mathrm{O}_{3}-\mathrm{YSZ}$ composite, and this shows that the ball milling was correctly carried out before

Table 1 Density of the composites measured in the pycnometer

\begin{tabular}{lll}
\hline Bulk density of powders $/ \mathrm{gcm}^{-3}$ & 5 mass $\% \mathrm{Al}_{2} \mathrm{O}_{3}-\mathrm{YSZ}$ & $25 \mathrm{mass}_{2} \mathrm{Al}_{2} \mathrm{O}_{3}-\mathrm{YSZ}^{-}$ \\
\hline Average & 4.5350 & 3.9933 \\
Standard deviation & 0.0109 & 0.0106 \\
\hline
\end{tabular}


preparing the disc-shaped samples and shows how the density of the composite is changed with addition of the $\mathrm{Al}_{2} \mathrm{O}_{3}$. The thermal diffusivity of the two types of the composite, one with 5 mass \% addition of $\mathrm{Al}_{2} \mathrm{O}_{3}$ in the $\mathrm{YSZ}$ and the second with 25 mass $\% \mathrm{Al}_{2} \mathrm{O}_{3}$ in the $\mathrm{YSZ}$, is presented in Figs. 1-5.

The thermal diffusivity values for both types of composites samples sintered at the temperature $1000{ }^{\circ} \mathrm{C}$ decrease with temperature to $0.15 \mathrm{~mm}^{2} \mathrm{~s}^{-1}$ at $700{ }^{\circ} \mathrm{C}$. Then the values for the composite with 5 mass $\% \mathrm{Al}_{2} \mathrm{O}_{3}$ start to increase to $0.18 \mathrm{~mm}^{2} \mathrm{~s}^{-1}$; on the other hand, the values for composite with 25 mass $\% \mathrm{Al}_{2} \mathrm{O}_{3}$ stayed at the same level. For the samples sintered at the temperature $1200{ }^{\circ} \mathrm{C}$, the change of the thermal diffusivity values has different tendency than for the temperature $1000{ }^{\circ} \mathrm{C}$. The values for the composite with 5 mass $\% \mathrm{Al}_{2} \mathrm{O}_{3}$ decrease to $0.33 \mathrm{~mm}^{2} \mathrm{~s}^{-1}$ at the temperature $600{ }^{\circ} \mathrm{C}$ and then stay at this level to $1100{ }^{\circ} \mathrm{C}$. At the same time, the values of the thermal diffusivity for the composite with 25 mass $\% \mathrm{Al}_{2} \mathrm{O}_{3}$

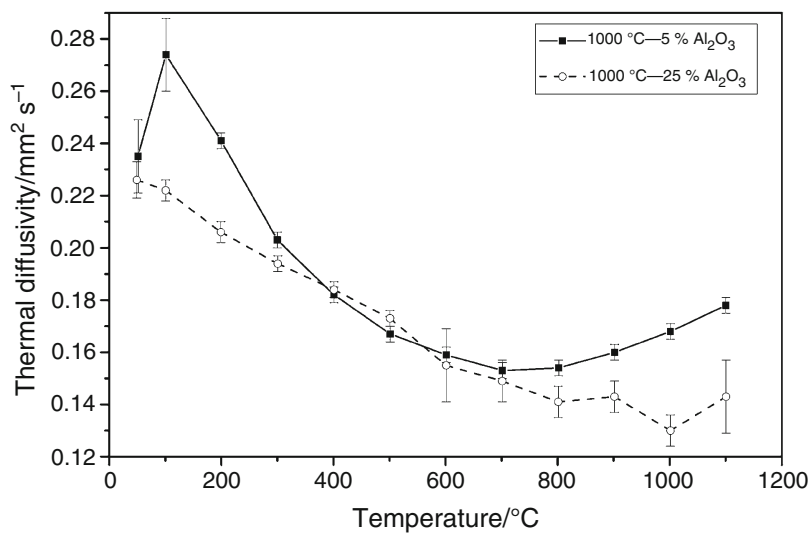

Fig. 1 Comparison of thermal diffusivity of 5 and 25 mass $\% \mathrm{Al}_{2} \mathrm{O}_{3}-$ YSZ composite in $1000{ }^{\circ} \mathrm{C}$

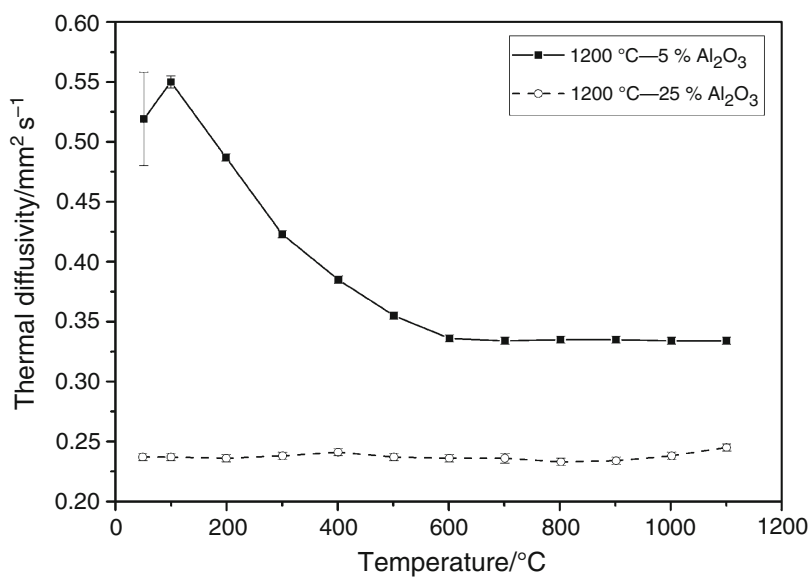

Fig. 2 Comparison of thermal diffusivity of 5 and 25 mass $\% \mathrm{Al}_{2} \mathrm{O}_{3}-$ YSZ composite in $1200{ }^{\circ} \mathrm{C}$ are equal to $0.23 \mathrm{~mm}^{2} \mathrm{~s}^{-1}$ for whole range of the measurement temperature. For $1400{ }^{\circ} \mathrm{C}$ sintering temperature, the thermal diffusivity for 25 mass $\% \mathrm{Al}_{2} \mathrm{O}_{3}$ has bigger values than for 5 mass $\% \mathrm{Al}_{2} \mathrm{O}_{3}$ and this is quite different from 1000 to $1200{ }^{\circ} \mathrm{C}$. It can be caused by the intrinsic cracks. The values of thermal diffusivity for the composite with 25 mass $\% \mathrm{Al}_{2} \mathrm{O}_{3}$ decrease to $0.36 \mathrm{~mm}^{2} \mathrm{~s}^{-1}$ at $800{ }^{\circ} \mathrm{C}$ and then insignificantly increase to $0.38 \mathrm{~mm}^{2} \mathrm{~s}^{-1}$. The values of thermal diffusivity for the composite with 5 mass $\% \mathrm{Al}_{2} \mathrm{O}_{3}$ increase from 0.23 to $0.29 \mathrm{~mm}^{2} \mathrm{~s}^{-1}$ in the whole range of measurement temperature. For $1600{ }^{\circ} \mathrm{C}$ sintering temperature, the values of thermal diffusivity for both composites have the same tendency and increase in the whole range of measurement temperature from 0.28 to $0.37 \mathrm{~mm}^{2} \mathrm{~s}^{-1}$ for 5 mass\% of $\mathrm{Al}_{2} \mathrm{O}_{3}$ and from 0.26 to $0.32 \mathrm{~mm}^{2} \mathrm{~s}^{-1}$ for 25 mass\% of $\mathrm{Al}_{2} \mathrm{O}_{3}$. In Fig. 5, all measurements are presented. The analysis for all sintering

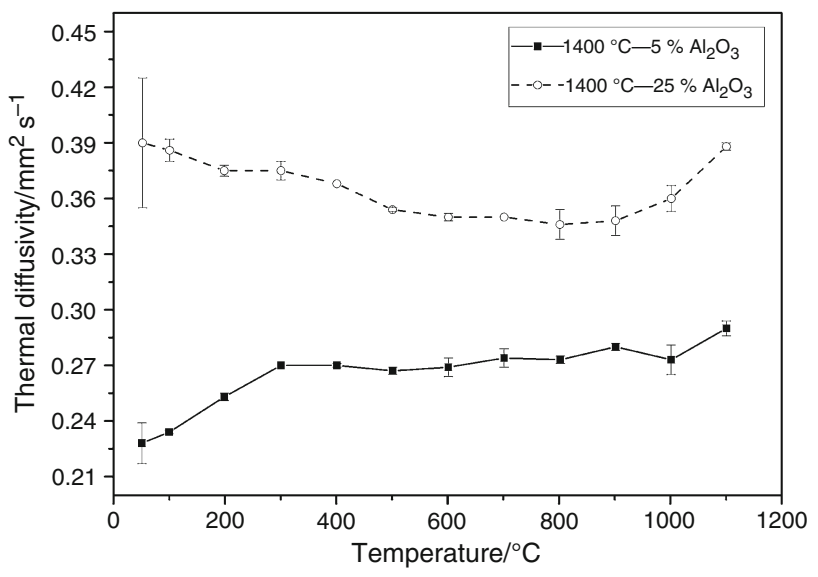

Fig. 3 Comparison of thermal diffusivity of 5 and 25 mass $\% \mathrm{Al}_{2} \mathrm{O}_{3}-$ YSZ composite in $1400{ }^{\circ} \mathrm{C}$

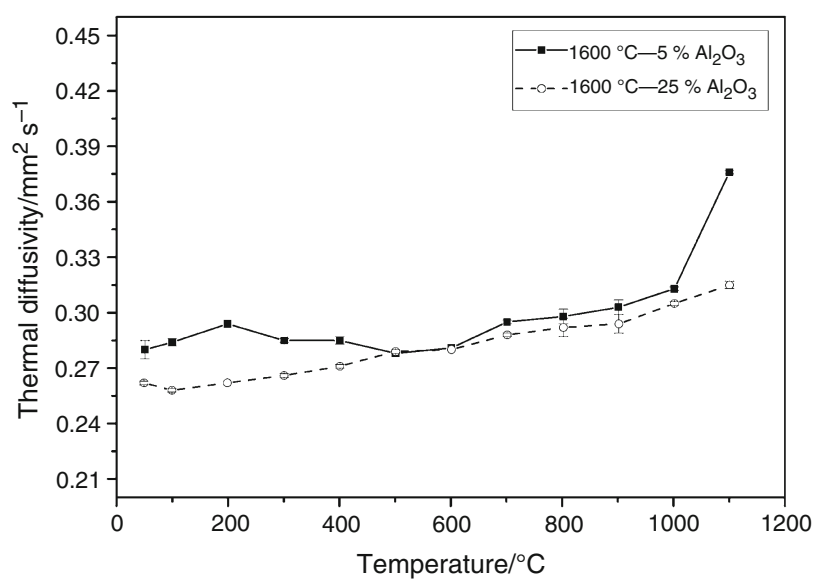

Fig. 4 Comparison of thermal diffusivity of 5 and 25 mass $\% \mathrm{Al}_{2} \mathrm{O}_{3}-$ YSZ composite in $1600^{\circ} \mathrm{C}$ 


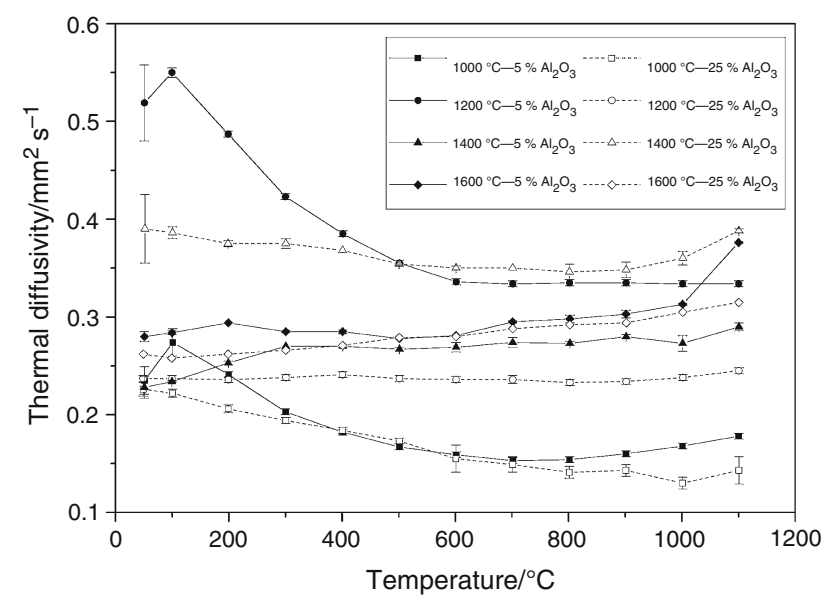

Fig. 5 Comparison of thermal diffusivity of 5 and 25 mass $\% \mathrm{Al}_{2} \mathrm{O}_{3}-$ YSZ composite in all temperatures

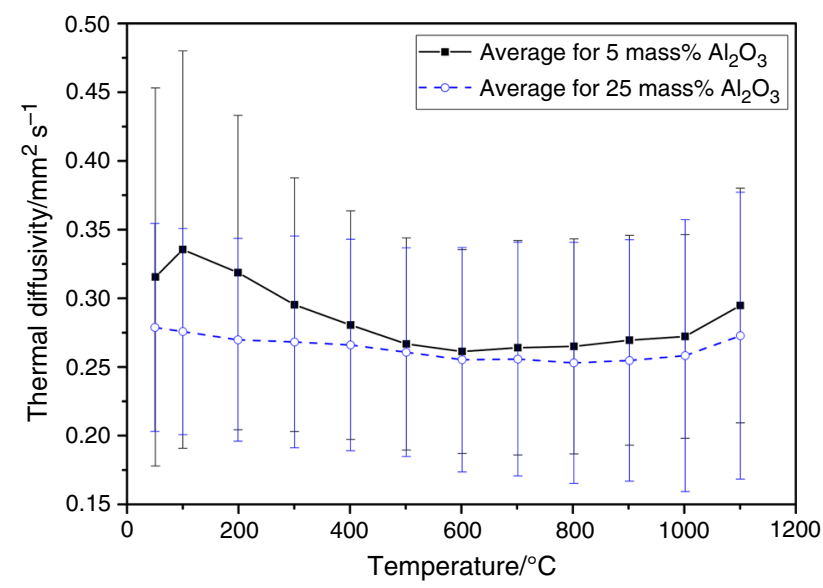

Fig. 6 Comparison of average thermal diffusivity of 5 and 25 mass $\%$ $\mathrm{Al}_{2} \mathrm{O}_{3}-\mathrm{YSZ}$

temperatures shows that there is no significant difference in the thermal diffusivity measured by laser flash for both composites in the temperatures 1400 and $1600{ }^{\circ} \mathrm{C}$. The considerable difference can be seen for the sintering temperatures -1000 and $1200{ }^{\circ} \mathrm{C}$. For both composites, the thermal diffusivity in this temperature has tendency to decrease with temperature. The average thermal diffusivity for both composites is measured and presented in Fig. 6 .

The SEM microscopic investigation of pressed and sintered $\mathrm{Al}_{2} \mathrm{O}_{3}-\mathrm{YSZ}$ composites was the basis for the analysis of their morphology and microstructure. The microstructure illustrates the effect of sintering temperature on morphology of the samples. It was found that the samples heated at temperatures of 1000 and $1200{ }^{\circ} \mathrm{C}$ for $4 \mathrm{~h}$ were not well sintered (Fig. 7a-d) and the morphology of YSZ and $\mathrm{Al}_{2} \mathrm{O}_{3}$ powder particles is angular while for the temperature of $1400{ }^{\circ} \mathrm{C}$ can be seen clearly sintering characteristics, the particles of $\mathrm{Al}_{2} \mathrm{O}_{3}$ and $\mathrm{YSZ}$ powders have a more rounded shape (Fig. 7e, f) than for samples sintered at 1000 and $1200{ }^{\circ} \mathrm{C}$. The microstructure of samples sintered at a temperature of $1600{ }^{\circ} \mathrm{C}$ is more uniform and dense and is characterized by a lower porosity (Fig. $7 \mathrm{~g}, \mathrm{~h}$ ). The EDS X-ray maps show that the dispersion of $\mathrm{Al}_{2} \mathrm{O}_{3}$ powder particles is similar for all the samples at all temperatures for both 5 and 25 mass $\% \mathrm{Al}_{2} \mathrm{O}_{3}$, and present are agglomerates of $\mathrm{YSZ}$ and $\mathrm{Al}_{2} \mathrm{O}_{3}$ (Fig. 8). Figure 9a, b illustrate the presence of the $\mathrm{Al}_{2} \mathrm{O}_{3}$ and $\mathrm{YSZ}$ powder particles in microstructure of $\mathrm{Al}_{2} \mathrm{O}_{3}-\mathrm{YSZ}$ composites for 25 mass $\%$ $\mathrm{Al}_{2} \mathrm{O}_{3}$ sintered at a temperature of $1000{ }^{\circ} \mathrm{C}$ and $1600{ }^{\circ} \mathrm{C}$.

The analysis of particle size distribution is presented in Fig. 10. The volume per cent for 5 mass $\% \mathrm{Al}_{2} \mathrm{O}_{3}-\mathrm{YSZ}$ composite and for 25 mass $\% \mathrm{Al}_{2} \mathrm{O}_{3}-\mathrm{YSZ}$ composite is presented in Fig. 10 and shows that after milling in the powder there is non-uniform distribution of the particle diameter. This causes creation of porosity in the pressed and sintered samples and can affect the thermal diffusivity measurements of ceramics samples in the laser technique as it can be seen in Figs. 1-4.

\section{Discussion}

The analysis of thermal diffusivity of the 5 and 25 mass\% $\mathrm{Al}_{2} \mathrm{O}_{3}-\mathrm{YSZ}$ composites in the temperature range $20-100{ }^{\circ} \mathrm{C}$ was presented. Figure 6 presents the average values of thermal diffusivity with standard deviation measured for both 5 and 25 mass $\% \mathrm{Al}_{2} \mathrm{O}_{3}-\mathrm{YSZ}$ composites on the samples sintered in the temperatures: 1000,1200 , 1400 and $1600{ }^{\circ} \mathrm{C}$. The average thermal diffusivity values of $\mathrm{Al}_{2} \mathrm{O}_{3}-\mathrm{YSZ}$ composite in the range of temperature $20-1100{ }^{\circ} \mathrm{C}$ show higher deviations for lower temperatures. This is due to the small amount of laser energy in comparison with heat loss effects. Akin et al. [17] show that for pure $\mathrm{Al}_{2} \mathrm{O}_{3}$ sample the displacement during sintering appears from 900 to $1300{ }^{\circ} \mathrm{C}$ and for $\mathrm{Al}_{2} \mathrm{O}_{3}$ $10 \mathrm{~mol} \%$ YSZ composites the displacement appears from 1200 to $1400{ }^{\circ} \mathrm{C}$. This can suggest that samples sintered below $1400{ }^{\circ} \mathrm{C}$ would be unstable for measuring thermal diffusivity by laser flash technique. Schlichting et al. [12] considered the influence of porosity on thermal conductivity and showed that the increase in porosity causes the decrease in values of thermal conductivity with increasing in temperature. In this study, the effect of porosity was not considered. In this publication, the thermal diffusivity for both composites increases after $1000{ }^{\circ} \mathrm{C}$ which is shown in Fig. 6. All authors $[12,13,17]$ considered thermal conductivity of $\mathrm{Al}_{2} \mathrm{O}_{3}-\mathrm{YSZ}$ composites after sintering samples in $1500{ }^{\circ} \mathrm{C}$. The authors of this publication considered the influence of sintering temperature from 1000 to $1600{ }^{\circ} \mathrm{C}$ on thermal diffusivity measured with laser flash technique. The results showed that for both 5 and 25 mass $\% \mathrm{Al}_{2} \mathrm{O}_{3}-\mathrm{YSZ}$ composites sintered in $1000{ }^{\circ} \mathrm{C}$ the thermal diffusivity 

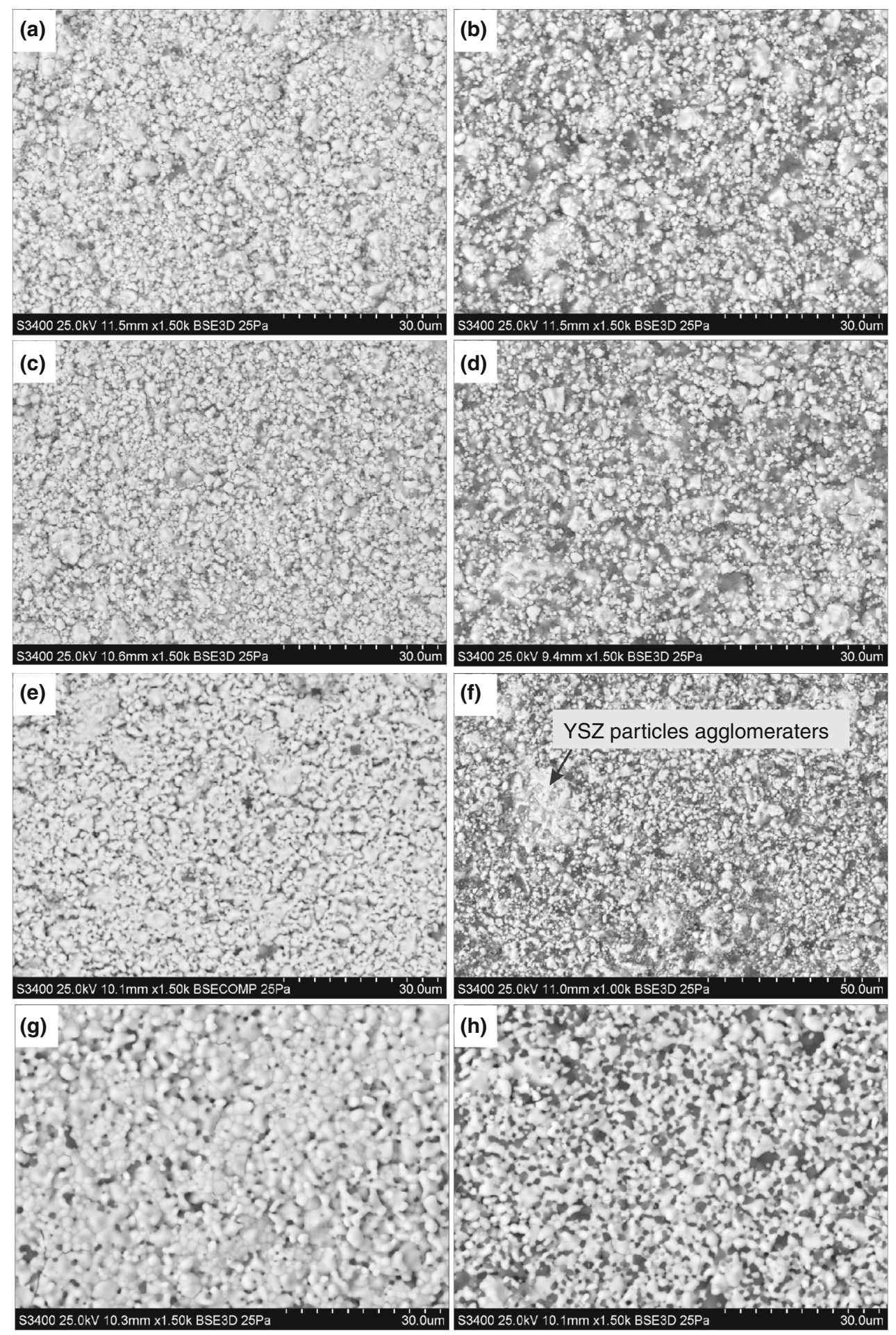

Fig. 7 SEM-BSE micrographs of sintered $\mathrm{Al}_{2} \mathrm{O}_{3}-\mathrm{YSZ}$ composites sintered at a temperature of a $1000{ }^{\circ} \mathrm{C} 5$ mass $\% \mathrm{Al}_{2} \mathrm{O}_{3} ; \mathbf{b} 1000{ }^{\circ} \mathrm{C} 25$ mass $\%$ $\mathrm{Al}_{2} \mathrm{O}_{3} ; \mathbf{c} 1200{ }^{\circ} \mathrm{C} 5$ mass $\% \mathrm{Al}_{2} \mathrm{O}_{3} ; \mathbf{d} 1200{ }^{\circ} \mathrm{C} 25$ mass $\% \mathrm{Al}_{2} \mathrm{O}_{3} ;$ e $1400{ }^{\circ} \mathrm{C} 5$ mass $\% \mathrm{Al}_{2} \mathrm{O}_{3} ;$ f $1400{ }^{\circ} \mathrm{C} 25$ mass $\% \mathrm{Al}_{2} \mathrm{O}_{3} ; \mathbf{g} 1600{ }^{\circ} \mathrm{C} 5$ mass $\%$ $\mathrm{Al}_{2} \mathrm{O}_{3} ; \mathbf{h} 1600{ }^{\circ} \mathrm{C} 25$ mass $\% \mathrm{Al}_{2} \mathrm{O}_{3}$

decreases with temperature. For temperatures 1200,1400 and $1600{ }^{\circ} \mathrm{C}$, the thermal diffusivity decreases up to $1000{ }^{\circ} \mathrm{C}$ and then increases. This can suggest the thermal conductivity of both 5 and 25 mass $\% \mathrm{Al}_{2} \mathrm{O}_{3}-\mathrm{YSZ}$ composites also increases.
The large value of deviation for thermal diffusivity suggests that the laser flash analysis for ceramic powder needs broader researches. The SEM microstructure investigations showed crucial differences in morphology studies composited in the 

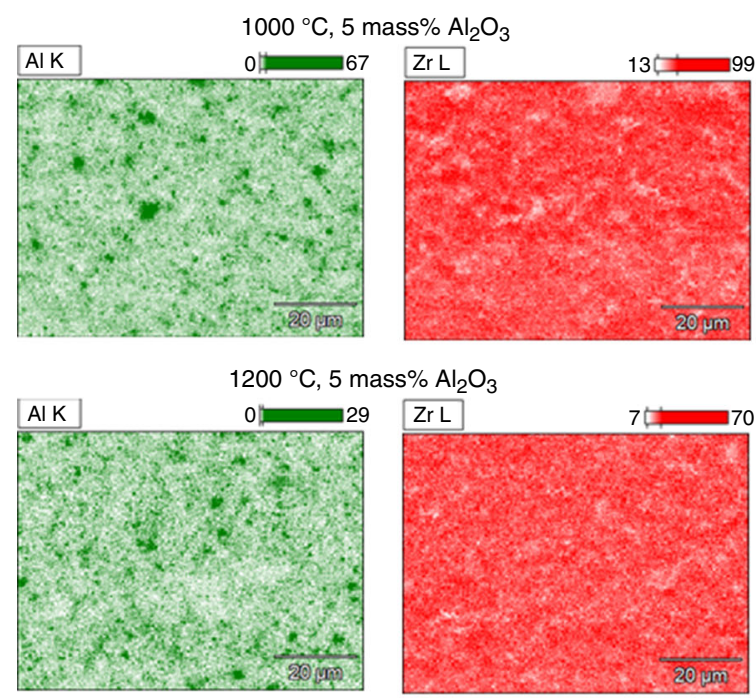

$1400{ }^{\circ} \mathrm{C}, 5$ mass $\% \mathrm{Al}_{2} \mathrm{O}_{3}$
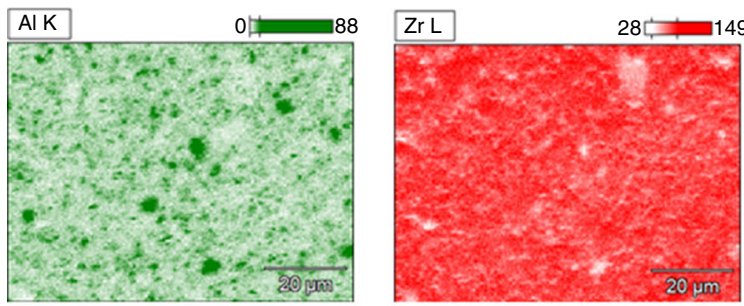

$1600{ }^{\circ} \mathrm{C}, 5$ mass $\% \mathrm{Al}_{2} \mathrm{O}_{3}$
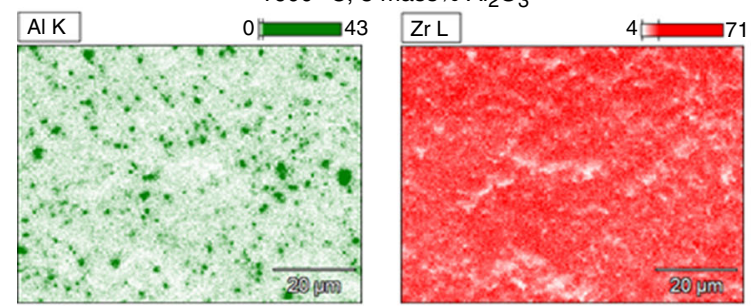

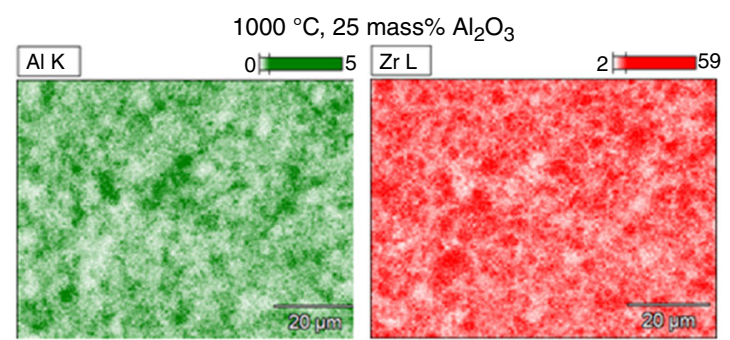

$1200{ }^{\circ} \mathrm{C}, 25$ mass $\% \mathrm{Al}_{2} \mathrm{O}_{3}$

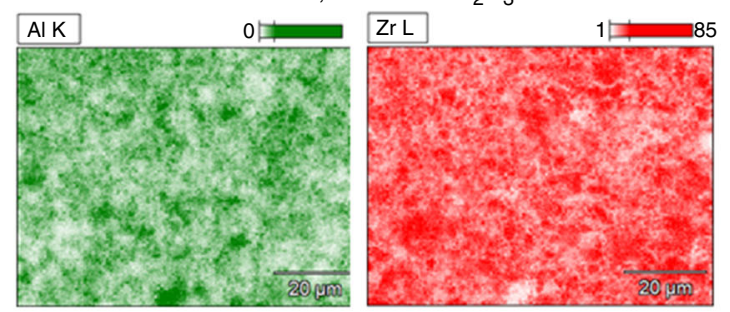

$1400{ }^{\circ} \mathrm{C}, 25$ mass $\% \mathrm{Al}_{2} \mathrm{O}_{3}$

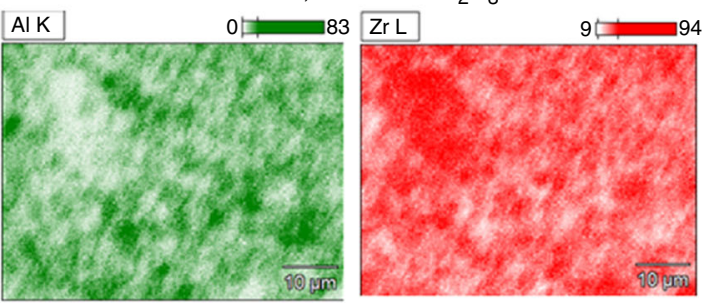

$1600{ }^{\circ} \mathrm{C}, 25$ mass $\% \mathrm{Al}_{2} \mathrm{O}_{3}$

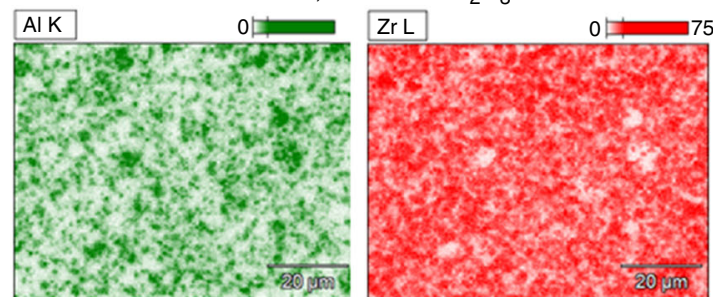

Fig. 8 Results of the EDS X-ray mapping analysis. The images show microareas of aluminium and zirconium concentrations in sintered YSZ$\mathrm{Al}_{2} \mathrm{O}_{3}$ composites
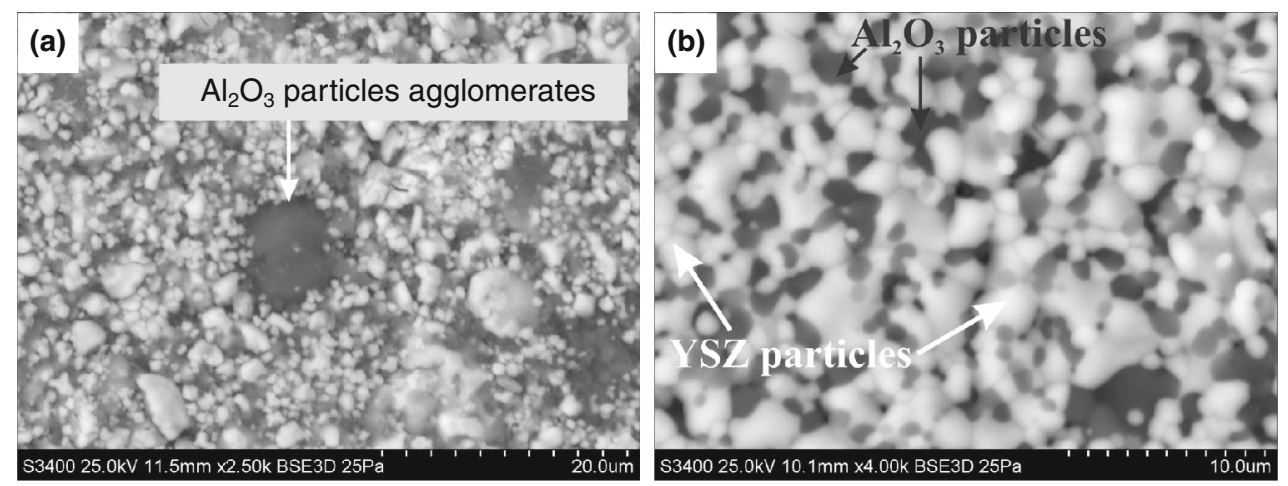

Fig. 9 SEM-BSE micrographs of morphology of $\mathrm{Al}_{2} \mathrm{O}_{3}-\mathrm{YSZ}$ composites for 25 mass $\% \mathrm{Al}_{2} \mathrm{O}_{3}$ sintered at a temperature of a $1000{ }^{\circ} \mathrm{C}$ and b $1600{ }^{\circ} \mathrm{C}$ 


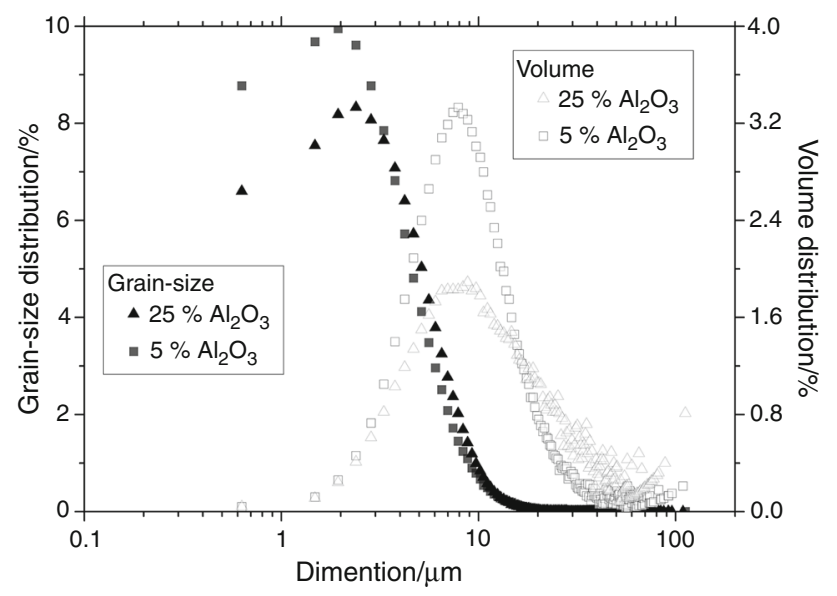

Fig. 10 Particle grain size and volume distribution for 5 and 25 mass $\% \mathrm{Al}_{2} \mathrm{O}_{3}-\mathrm{YSZ}$ composite

influence of sintering temperature. The analysis of particle size distribution shows non-uniform particle diameter. This causes bigger non-stability in the laser flash measurements and can be the source of intrinsic cracks in the ceramics samples prepared for thermal diffusivity measurements. The average values of thermal diffusivity for 5 and 25 mass $\%$ $\mathrm{Al}_{2} \mathrm{O}_{3}-\mathrm{YSZ}$ composites measured by laser flash method in this paper showed differences in comparison with others values presented in literature. The $\mathrm{Al}_{2} \mathrm{O}_{3}-\mathrm{YSZ}$ composite is well known, and its thermal properties are the subject of the researches since long time. Nevertheless, the influence of each oxide's chemical composition, porosity and size of particles in the composite is still unknown. It should be noted that in present work an influence of the porosity and density of $\mathrm{Al}_{2} \mathrm{O}_{3}-\mathrm{YSZ}$ composites on their thermal conductivity and diffusivity was not taken into account and it will be the subject of further research.

Open Access This article is distributed under the terms of the Creative Commons Attribution 4.0 International License (http://crea tivecommons.org/licenses/by/4.0/), which permits unrestricted use, distribution, and reproduction in any medium, provided you give appropriate credit to the original author(s) and the source, provide a link to the Creative Commons license, and indicate if changes were made.

\section{References}

1. Strangman TE. Thermal barrier coatings for turbine airfoils. Thin Solid Films. 1985;127:93-105.

2. Evans AG, et al. Mechanisms controlling the durability of thermal barrier coatings. Prog Mater Sci. 2001;46(46):505-53.

3. Swadźba L, Moskal G, Mendala B, Gancarczyk T. Characterisation of APS TBC system during isothermal oxidation at $1100{ }^{\circ}$ C. Adv Mater Sci Eng. 2007;28(12):757-64.
4. Padture NP. Thermal barrier coatings for gas-turbine engine applications. Science. 2002;296(5566):280-4.

5. Schulz U. Microstructure and texture of EB-PVD TBCs grown under different rotation modes. Mater Sci Eng A. 2003; 360(1-2):319-29.

6. Von Niessen K, Gindrat M, Refke A. Vapor phase deposition using plasma spray-PVD ${ }^{\mathrm{TM}}$. J Therm Spray Technol. 2010; 19(1-2):502-9.

7. Góral M, Kotowski S, Nowotnik A, Pytel M, Drajewicz M, Sieniawski J. PS-PVD deposition of thermal barrier coatings. Surf Coat Technol. 2013;237:51-5.

8. Munawar AU, Schulz U, Cerri G. Microstructural evolution of GdZ and DySZ based EB-PVD TBC systems after thermal cycling at high temperaturę. J Eng Gas Turbines Power. 2013;135(10):1-6.

9. Schulz U. Phase transformation in EB-PVD yttria partially stabilized zirconia thermal barrier coatings during annealing. J Am Ceram Soc. 2000;83(4):904-10.

10. Drajewicz M, Dychton K, Goral M. Thermal properties of YSZ powders for plasma spraying. Solid State Phenom. 2015;227: 413-6.

11. Tojo T, Atake T, Mori T, Yamamura H. Excess heat capacity in yttria stabilized zirconia. J Therm Anal Calorim. 1999;57(2):447-58.

12. Schlichting KW, Padture NP, Klemens PG. Thermal conductivity of dense and porous yttria-stabilized zirconia. J Mater Sci. 2001;36(12):3003-10.

13. Angle JP, Wang Z, Dames C, Mecartney ML. Comparison of two-phase thermal conductivity models with experiments on dilute ceramic composites. J Am Ceram Soc. 2013;96(9): 2935-42.

14. Chen M, Hallstedt B, Gauckler LJ. Thermodynamic modeling of the $\mathrm{ZrO}_{2}-\mathrm{YO}_{1.5}$ system. Solid State Ion. 2004;170(3-4):255-74.

15. Ravichandran KS, An K, Dutton RE, Semiatin SL. Thermal conductivity of plasma-sprayed monolithic and multilayer coatings of alumina and yttria-stabilized zirconia. J Am Ceram Soc. 1999;82(3):673-82.

16. Hofmeister AM. Thermal diffusivity and thermal conductivity of single-crystal $\mathrm{MgO}$ and $\mathrm{A} 12 \mathrm{O} 3$ and related compounds as a function of temperature. Phys Chem Miner. 2011;41(5):361-71.

17. Akin I, Yilmaz E, Sahin F, Yucel O, Goller G. Effect of $\mathrm{CeO} 2$ addition on densification and microstructure of $\mathrm{Al}_{2} \mathrm{O}_{3}-\mathrm{YSZ}$ composites. Ceram Int. 2014;37(8):3273-80.

18. Hotza D, Leo A, Sunarso J, da Diniz Costa JC. Effect of Nano$\mathrm{Al}_{2} \mathrm{O}_{3}$ addition on the densification of YSZ electrolytes. J Nano Res. 2009;9:115-22.

19. Manuelian M, Campbell R. Thermal diffusivity, specific heat, and thermal conductivity measurment using NETZSCH LFA 447 Nanoflash $^{\text {TM }}$. Netzsch Instrum. 2008;1-8.

20. Oksanen M, Volcan A, Fenici P. Simulations on the accuracy of laser-flash data analysis methods. Rev Prog Quant Nondestr Eval. 1996;15:549-52.

21. Parker WJ, Jenkins RJ, Butter CP, Abbot GL. Flash method of determining thermal diffusivity, heat capacity and thermal conductivity. J Appl Phys. 1961;32:1679-84.

22. Shinzato K, Baba T. A laser flash apparatus for thermal diffusivity and specific heat capacity measurements. J Therm Anal Calorim. 2001;64:413-22.

23. Gaal PS, Thermitus MA, Stroe DE. Thermal conductivity measurements using the flash method. J Therm Anal Calorim. 2004;78:185-9. 